\title{
PERENCANAAN PEMBIAYAAN PENDIDIKAN (Studi Kasus di Sekolah Dasar)
}

\author{
Dedy Achmad K 1); Gilang Gumilang D; dan Herlina 2) \\ ${ }^{1}$ Dosen Administrasi Pendidikan Fakultas Ilmu Pendidikan
}

\begin{abstract}
Financial planning education, especially regarding the analysis of the needs of education ( elementary school ) in the future should be able to run, so that the achievement of the plan can be realized well with effective management and efficient budget. Educational arrangements referred to in this article is how governments, agencies or schools can plan sees the need for schools, classrooms and teachers in the community standard which is based on meeting the minimum standards of education. The aim is to assist in the distribution of education and know the real condition of the school in the community. Schools targeted mainly primary school level are included in compulsory education launched by the government .
\end{abstract}

Keywords : Planning, Financing, Budgeting and Mapping Guru

\section{A. Latar Belakang}

Perencanaan

merupakan

serangkaian kegiatan yang dilakukan untuk menetapkan tujuan organisasi, strategi, program dan kegiatan yang akan dilaksanakan untuk mencapai tujuan organisasi tersebut. Pentingnya perencanaan tertuang dalam istilah jika gagal dalam sebuah perencanaan maka telah merencanakan kegagalan. Menurut Kauffman (Fattah,1999:49) perencanaan merupakan "proses penentuan tujuan atau sasaran yang hendak dicapai, menetapkan jalan dan sumber yang diperlukan untuk mencapai tujuan secara efektif dan efisien". Fakry (Sa'ud dan Makmun, 2007: 4) mengemukakan bahwa:

Perencanaan dapat diartikan sebagai proses penyusunan berbagai keputusan yang akan dilaksanakan pada masa yang akan datang untuk mencapai tujuan yang telah ditentukan. Perencanaan itu dapat pula diberi arti sebagai suatu proses pembuatan serangkaian kebijakan untuk mengendalikan masa depan sesuai yang ditentukan. Perencanaan dapat pula diartikan sebagai upaya untuk memadukan antara cita-cita nasional dan resources yang tersedia yang diperlukan untuk mewujudkan citacita tersebut.

Banghart and Trull (Sagala, 2007) mengemukakan ada sembilan tujuan yang ingin dicapai dalam membuat sebuah perencanaan terutama perencanaan pendidikan yaitu: (1) untuk standar pengawasan pola perilaku pelaksana pendidikan, yaitu untuk mencocokkan antara pelaksanaan atau tindakan pemimpin dan anggota organisasi pendidikan dengan program atau perencanaan yang telah disusun; (2) untuk mengetahui kapan pelaksanaan perencanaan pendidikan itu diberlakukan dan bagaimana proses penyelesaian suatu kegiatan layanan pendidikan; (3) untuk mengetahui siapa saja yang terlibat (struktur organisasinya) dalam pelaksanaan program atau perencanaan pendidikan, baik aspek kualitas maupun kuantitasnya, dan baik menyangkut aspek akademik-nonakademik; (4) untuk mewujudkan proses kegiatan dalam pencapaian tujuan pendidikan secara 
efektif dan sistematis termasuk biaya dan kualitas pekerjaan; (5) untuk meminimalkan terjadinya beragam kegiatan yang tidak produktif dan tidak efisien, baik dari segi biaya, tenaga dan waktu selama proses layanan pendidikan; (6) untuk memberikan gambaran secara menyeluruh (integral) dan khusus (spefisik) tentang jenis kegiatan atau pekerjaan bidang pendidikan yang harus dilakukan; (7) untuk menyerasikan atau memadukan beberapa sub pekerjaan dalam suatu organisasi pendidikan sebagai suatu sistem; (8) untuk mengetahui beragam peluang, hambatan, tantangan dan kesulitan yang dihadapi organisasi pendidikan; dan (9) untuk mengarahkan proses pencapaikan tujuan pendidikan.

Ciri-ciri atau karakteristik dari suatu perencanaan pendidikan antara lain, perencanaan pendidikan harus: (1) berorientasi pada visi, misi kelembagaan yang akan diwujudkan; (2) mempunyai tahapan program jangka waktu tertentu (jangka pendek, menengah dan panjang) yang akan dicapai secara berkesinambungan; (3) mengutamakan nilai-nilai manusiawi, kerena pendidikan itu membangun manusia yang berkualitas, yang bermanfaat bagi dirinya dan masyarakatnya; (4) memberikan kesempatan untuk mengembangkan segala potensi peserta didik secara maksimal; (5) komprehensif dan sistematis dalam arti tidak praktikal atau segmentasi tetapi menyeluruh, terpadu (integral) dan disusun secara logis, rasional serta mencakup berbagai jalur, jenis dan jenjang pendidikan; (6) diorientasikan untuk mempersiapkan kualitas sumber daya manusia (SDM) yang berkualitas, yang sanggup mengisi berbagai sektor pembangunan; (7) dikembangkan dengan memperhatikan keterkaitannya dengan berbagai komponen pendidikan secara sistematis; (8) menggunakan sumber daya (resources) internal dan eksternal secermat mungkin; (9) berorientasi kepada masa datang, karena pendidikan adalah proses jangka panjang dan jauh untuk menghadapi berbagai persoalan di masa depan; (10) responsif terhadap kebutuhan yang berkembang di masyarakat dan bersifat dinamik; dan (11) merupakan sarana untuk mengembangkan inovasi pendidikan, sehingga proses pembaharuan pendidikan terus berlangsung dengan baik (Banghart and Trull dalam Sa'ud dan Makmun, 2007:31).

\section{B. Maksud dan Tujuan}

Maksud dan tujuan secara umum dalam penulisan ini adalah untuk mengetahui bagaimana keterkaitan antara perencanaan dengan pembiayaan pendidikan dalam rangka pemetaan guru pada tingkat sekolah dasar. Dalam artikel ini di bahas kajian data mengenai proyeksi penduduk, kebutuhan sekolah, kebutuhan rombongan belajar serta mengenai analisis kebutuhan guru. Perencanaan pembiayaan pendidikan khususnya mengenai analisis kebutuhan pendidikan (sekolah) di masa yang akan datang harus mampu dikelola dengan baik, agar hasil pencapaian dari rencana dapat terealisasi dengan baik dengan pengelolaan yang efektif dan anggaran yang efisien.

\section{Landasan Teori}

Istilah ekonomi dan pendidikan masing-masing memiliki pengertian yang berbeda. Ekonomi merupakan usaha memanfaatkan segala sumber daya untuk memproduksi komoditas tertentu, sedangkan pendidikan sebagai upaya untuk mencerdaskan manusia melalui pengembangan pengetahuan, sikap dan keterampilan supaya berdaya. (Dadang, dkk, 2012:4). Alasan kebutuhan dalam memahami ekonomi pendidikan dikarenakan bahwa proses pengembangan sumber daya manusia memerlukan alokasi biaya yang sangat besar yang harus dikelola secara rasional atas pemakaiannya. alasan kebutuhan dalam 
memahami ekonomi pendidikan dikarenakan bahwa proses pengembangan sumber daya manusia memerlukan alokasi biaya yang sangat besar yang harus dikelola secara rasional atas pemakaiannya

Pembiayaan merupakan bagian dari manajemen yang merupakan bagian dari ruang lingkupnya. Dalam pendidikan pembiayan merupakan faktor terpenting dalam menentukan kelangsungan hidup sekolah. Pembiayaan dalam pendidikan meliputi biaya langsung (direct cost) dan biaya tidak langsung (indirect cost). Biaya langsung terdiri dari biaya-biaya yang dikeluarkan untuk keperluan pelaksanaan pengajaran dan kegiatan belajar siswa berupa pembelian alat-alat pelajaran, sarana belajar, biaya transportasi, gaji guru, baik yang dikeluarkan oleh pemerintah, orang tuan, maupun oleh siswa itu sendiri. Sedangkan biaya tidak langsung merupakan pengeluaran yang tidak secara langsung menunjang proses pendidikan tetapi memungkinkan proses pendidikan tersebut terjadi di sekolah, misalnya biaya hidup siswa, biaya transportasi ke sekolah, biaya jajan, dan harga kesempatan (opportunity cost) (Nanang Fattah, 2009: 23).

Dalam Peraturan Pemerintah Nomor 19 Tahun 2007 pasal 62 disebutkan bahwa biaya pendidikan terdiri:

1. Biaya investasi satuan pendidikan meliputi biaya penyediaan sarana dan prasarana, pengembangan sumber daya manusia, dan modal kerja tetap.

2. Biaya personal meliputi biaya pendidikan yang harus dikeluarkan oleh peserta didik untuk bias mengukuti proses pembelajaran secara teratur dan berkelanjutan.

3. Biaya operasional satuan pendidikan meliputi: gaji pendidik dan tenaga kependidikan serta segala tunjangan yang melekat pada gaji; bahan atau peralatan habis pakai; dan biaya operasi pendidikan tak langsung berupa daya, air, jasa telekomunikasi, uang lembur, transportasi, konsumsi, pajak, asuransi, dan lain sebagainya.
Stanley J. Spanbauer, (1992:98) dalam Dadang Dkk, (2012:70) menyatakan bahwa ada tujuh unsur dalam menegakkan mutu pendidikan yang harus dibiyai, yaitu:

1. Human Resources

2. Curricukum and Instruction

3. Goal setting (standard of exillence for desing and implementation of operation)

4. Technology (standard Technology for used)

5. Marketing

6. Customers Service

7. Management (providing leadership of the quality improvement)

Perencanaan pendidikan yang dimaksud dalam artikel ini adalah bagaimana pemerintah, dinas ataupun sekolah dapat melakukan merencanakan melihat kebutuhan akan sekolah, ruang kelas, dan standar guru dimasyarakat yang di dasarkan pada pemenuhan standar minimal pendidikan. Tujuannya adalah untuk membantu dalam pemerataan pendidikan dan mengetahui kondisi sekolah secara rill di masyarakat. Sekolah yang menjadi sasaran terutama ditingkat sekolah dasar yang termasuk dalam wajib belajar yang dicanangkan pemerintah.

Perencanaan pendidikan dalam pemenuhan SPM ini berhubungan dengan banyak hal diantaranya adalah analisis proyeksi penduduk selama 5 tahun ke depan sehingga dengan begitu kita akan mengetahui selama lima tahun ke depan berapa kebutuhan sekolah yang yang harus dibangun oleh pemerintah dan akan berujung pada keuangan atau pembiayaan yang dibutuhkan dalam pembuatan sekolah baru bagi sekolah yang kekurangan, pembuatan ruang kelas baru bagi kebutuhan ruang kelas, dan rencana biaya untuk melanjutkan studi ataupun PLPG guru bagi guru yang belum memenuhi standar dan belum tersertifikasi.

Pembiayaan pendidikan merupakan instrumen penting dalam pencapaian tujuan, sebagus dan sehebat apapun program pendidikan itu tanpa konsep 
perencanaan pembiayaan yang matang maka program tersebut sulit untuk dapat direalisasikan. Kalaupun terrealisasi maka hanya menimbulkan keborosan biaya. Munculnya SPM akan membantu dalam merinci anggaran pendiidkan yang dibutuhkan untuk setiap detailnya. Meskipun pada kenyataannya daerah belum siap dengan hal ini dikarenakan kurangnya sumber daya manusia yang mengerti akan perhitungan perencanaan pembiayaan dan pemenuhan SPM yang belum terpenuhi sehingga perencanaan pendidikan tidak dilakukan dengan baik.

Perencanaan

pembiayan

pendidikan haruslah dilakukan dengan baik, pemerintah harus dapat menganggarkan pada pemenuhan kualitas pendidikan dan pembangunan pendidikan bukan hanya terfokus pada gaji guru, infrastruktur juga harus diperhatikan. Tetapi sayangnya pemerintah kita melakukan perencanaan anggarannya dulu tanpa menetapkan target program sehingga yang terjadi adalah anggaran ada dan program tidak jelas yang menghasilkan anggaran yang tersedia digunakan untuk program apapun yang terkadang tidak jelas.

Dalam permendiknas nomor 69 tahun 2009 tentang biaya operasi nonpersonal SD/MI terdiri dari: 6 rombongan belajar dengan setiap rombongan belajar berisi 28 peserta didik. Untuk Tabel Standar Biaya Operasi Nonpersonalia per Sekolah/Program Keahlian, per Rombongan Belajar, dan per Peserta Didik untuk SD/MI, dapat dilihat pada tabel di bawah ini.

Tabel 1. Tabel Standar Biaya Operasi Nonpersonalia per Sekolah/Program Keahlian, per Rombongan Belajar, dan per Pe serta Didik untuk SD/MI

\begin{tabular}{|c|c|c|c|c|c|c|}
\hline \multirow{3}{*}{ NO } & \multirow{2}{*}{\begin{tabular}{c} 
Sekolah \\
\cline { 3 - 5 }
\end{tabular}} & $\begin{array}{c}\text { Per Sekolah/ } \\
\text { Program } \\
\text { Keahlian }\end{array}$ & $\begin{array}{c}\text { Per } \\
\text { Rombongan } \\
\text { Belajar }\end{array}$ & $\begin{array}{c}\text { Per } \\
\text { Peserta } \\
\text { Didik }\end{array}$ & $\begin{array}{c}\% \\
\text { Minimum } \\
\text { untuk ATS }\end{array}$ & $\begin{array}{c}\text { Minimum } \\
\text { untuk } \\
\text { BAHP }\end{array}$ \\
\hline 1. & SD/MI & 97.440 & 16.240 & 580 & 10 & 10 \\
\hline
\end{tabular}

Sumber: Hasil Olahan Penelitian

Tabel diatas merupakan tabel

BPS, dilakukan perhitungan akan standar biaya non personalia untuk SD/MI dalam kondisi ini di DKI Jakarta. Sedangkan untuk masing-masing daerah di luar DKI Jakarta ditetapkan indeks yang menjadi pengali dengan biaya standar sekolah di DKI Jakarta. Untuk kabupaten tasikmalaya, indeks pengalinya adalah 0,907 .

\section{Pembahasan}

Berdasarkan latar belakang masalah dan berbagai teori yang telah diuraikan tersebut, pada bagian ini akan diuraikan contoh kasus di suatu daerah, yaitu yang dijadikan sebagai contoh pada kabupaten tasikmalaya yang merupakan salah satu daerah yang ada di provinsi jawa barat dengan luas wilayah 2.712,52 $\mathrm{km}^{2}$ dan dengan jumlah penduduk 1.676.544 jiwa (2010), didapat dari data

kebutuhan sekolah dan biaya yang dibutuhkan sebagai berikut:

\section{Proyeksi penduduk}

Untuk mengetahui kebutuhan sekolah pada tahun-tahun berikutnya ddi suatu wilayah dalam SPM dikatakan bahwa minimal setiap 1000 penduduk ada 1 sekolah yang melayani kebutuhan pendidikan masyarakat dengan jarak tidak lebih dari $3 \mathrm{KM}$ dari pemukiman penduduk. Untuk mengetahui kenaikan setiap tahunnya maka dibutuhkan kenaikan rata-rata tiap tahun pada daerah tersebut.

Untuk mengetahui kenaikan ratarata tiap tahun dari jumlah penduduk yang ada di kabupaten tasikmalaya, maka kita memerlukan data minimal 5 tahun terakhir, yaitu: 
Tabel 2. Data Kenaikan Rata-Rata Jumlah Penduduk Per Tahun

Dimana:

\begin{tabular}{|c|c|}
\hline Tahun & $\begin{array}{c}\text { Jumlah } \\
\text { Penduduk }\end{array}$ \\
\hline 2012 & 1.716 .178 \\
\hline 2011 & 1.692 .432 \\
\hline 2010 & 1.675 .675 \\
\hline 2009 & 1.727 .320 \\
\hline 2008 & 1.707 .297 \\
\hline \multicolumn{2}{|c|}{ (data di dapat dari BPS) }
\end{tabular}

Setelah memperoleh data diatas, maka dilakukan perhitungan dengan rumus:

$$
t=\frac{t t-t 2}{t 1} \times 100 \%
$$

$\mathrm{t}=$ kenaikan

$\mathrm{tt}=$ tahun pertama

$\mathrm{t} 2=5$ tahun ke belakang (tahun sebelum)

$\mathrm{t} 1=$ tahun pertama

Kenaikan pada 5 tahun terakhir mencapai $0,52 \%$ sehingga rata-rata pertahun adalah $0,104 \%$ sehingga proyeksi penduduk pada 5 tahun mendatang adalah:

Tabel 3. Proyeksi Penduduk Pada Lima Tahun Ke Depan

\begin{tabular}{|c|c|}
\hline Tahun & Penduduk \\
\hline 2012 & 1.716 .178 \\
\hline 2013 & 1.717 .963 \\
\hline 2014 & 1.719 .751 \\
\hline 2015 & 1.721 .540 \\
\hline 2016 & 1.723 .331 \\
\hline 2017 & 1.725 .124 \\
\hline
\end{tabular}

Sumber: Hasil Olahan Penelitian

Dilihat dari data, kenaikan tiap tahun di kabupaten tasikmalaya tidak terlalu besar sehingga masih normal dan tidak perlu dikhawatirkan. Kenaikan penduduk akan berdampak pada jumlah sekolah yang harus disiapkan dan guru yang diperlukan serta berdampak pada anggaran yang harus dipersiapkan oleh pemerintah ketika terjadi kekurangan sekolah atau guru yang sesuai dengan kualifikasi

\section{Proyeksi sekolah dasar}

Setelah melihat jumlah penduduk pada lima tahun ke depan maka yang selanjutnya adalah memprediksi kebutuhan sekolah dasar yang dibutuhkan sehingga semua penduduk yang akan bersekolah di sekolah dasar pada khususnya terlayani. Kebutuhan akan sekolah dasar dihitung dari jumlah penduduk dibagi dengan 1000 penduduk, asumsinya bahwa setiap 1000 penduduk terdapat satu sekolah dasar. sehingga di dapat data:

Tabel 4. As umsi Kenaikan Per 1000 Penduduk

\begin{tabular}{|l|l|l|}
\hline Tahun & Penduduk & Kebutuhan Sekolah \\
\hline
\end{tabular}




\begin{tabular}{|l|l|l|}
\hline 2012 & 1.716 .178 & 1.716 \\
\hline 2013 & 1.717 .963 & 1.718 \\
\hline 2014 & 1.719 .751 & 1.720 \\
\hline 2015 & 1.721 .540 & 1.722 \\
\hline 2016 & 1.723 .331 & 1.723 \\
\hline 2017 & 1.725 .124 & 1.725 \\
\hline
\end{tabular}

Sumber: Hasil Olahan Penelitian

Pada tahun 2012, di ketahui jumlah sekolah sekolah dasar yang telah ada adalah sebanyak 1.085 sedangkan yang dibutuhkan adalah 1.716 sehingga masih dibutuhkan sekolah sebanyak 631 sekolah. Melihat pada data di atas, maka penambahan jumlah sekolah tiap tahun adalah dua sekolah. Sehingga pemerintah harus mempersiapkan anggaran untuk menambah sekolah jika melihat pada pertumbuhan penduduk. Selain menambah sekolah tentu pemerintah juga harus menngkatkan sekolah swasta untuk dapat membantu

\section{Proyeksi Kebutuhan Rombel}

Tabel 5. Proyeksi Kebutuhan Rombel

\begin{tabular}{|c|c|c|c|}
\hline Tahun & Penduduk & $\begin{array}{c}\text { Kebutuhan } \\
\text { Sekolah }\end{array}$ & $\begin{array}{c}\text { Rombel @ 32 } \\
\text { orang/Rombel }\end{array}$ \\
\hline 2012 & 1.716 .178 & 1.716 & 10.297 \\
\hline 2013 & 1.717 .963 & 1.718 & 10.308 \\
\hline 2014 & 1.719 .751 & 1.720 & 10.319 \\
\hline 2015 & 1.721 .540 & 1.722 & 10.329 \\
\hline 2016 & 1.723 .331 & 1.723 & 10.340 \\
\hline 2017 & 1.725 .124 & 1.725 & 10.351 \\
\hline
\end{tabular}

Sumber: Hasil Olahan Penelitian

Dilihat dari data di atas, terdapat perkembangan kebutuhan rombel yang diperoleh dari jumlah kebutuhan sekolah di kali dengan 32 siswa dengan standar pelayanan minimum yang mengatakan bahwasetiap 1 rombel terdiri dari 32 orang siswa. Pada tahun 2012, jumlah rombel yang ada adalah 7.109 dan yang seharusnya adalah 10.297 sehingga dinas harus menambah rombel sebanyak 3.188 rombel. Tetapi untuk tahun 2012, ditemukan data jumlah siswa yang masuk sekolah dasar sehingga kebutuhan rombel jika disesuaikan dengan jumlah siswa sebanyak 203.717 maka rombel yang dibutuhkan adalah 6366 yang didapat dari pembagian jumlah siswa dengan rombel yang berisi 32 siswa. Sehingga pada tahun 2012, ada kelebihan rombel sebanyak 743. Hal ini bisa dikarenakan kurang meratanya jumlah siswa tiap kecamatan sehingga banyak rombel yang diisi kurang dari 32 siswa tetapi di kecamatan yang padat malah lebih dari 32 orang siswa. 
Dinas seharusnya dapat menganalisis mana daerah yang padat dengan daerah yang kurang padat sehingga untuk daerah yang padat sebaiknya dibangun sekolah jika lahannya memenuhi tetapi jika lahannya tidak memenuhi maka sebaiknya rombel ditambah. Dilihat dari data diatas, dengan adanya kelebihan rombel maka seharusnya dinas menambah sekolah sesuai dengan jumlah penduduk per-kecamatan.

\section{Proyeksi kebutuhan guru}

Tabel 6. Proyeksi Kebutuhan Guru

\begin{tabular}{|c|c|c|c|c|c|}
\hline Tahun & Penduduk & $\begin{array}{c}\text { Kebutuhan } \\
\text { Sekolah }\end{array}$ & $\begin{array}{c}\text { Rombel @ 32 } \\
\text { orang } \\
\text { /Rombel }\end{array}$ & Guru & Guru S1 \\
\hline 2012 & 1.716 .178 & 1.716 & 10.297 & 10.297 & 6.865 \\
\hline 2013 & 1.717 .963 & 1.718 & 10.308 & 10.308 & 6.872 \\
\hline 2014 & 1.719 .751 & 1.720 & 10.319 & 10.319 & 6.879 \\
\hline 2015 & 1.721 .540 & 1.722 & 10.329 & 10.329 & 6.886 \\
\hline 2016 & 1.723 .331 & 1.723 & 10.340 & 10.340 & 6.893 \\
\hline 2017 & 1.725 .124 & 1.725 & 10.351 & 10.351 & 6.900 \\
\hline
\end{tabular}

Sumber: Hasil Olahan Penelitian

Kebutuhan guru didapat dari jumlah sekolah disesuaikan dengan jumlah rombel yang ada. Untuk sekolah dasar asumsinya adalah 1 rombel harus diisi oleh 1 orang guru dan 1 sekolah harus ada 6 orang guru. Sehingga di dapat data seperti di atas. Pada tahun 2012, jumlah guru sekolah dasar adalah 10.236 sehingga ada kekurangan guru sebanyak 61 orang. Dari setiap sekolah dasar, guru yang berlatar belakang pendidikan $S 1$ harus berjumlah 4 orang. Dari jumlah guru yang ada yang berlatar belakang pendidikan sarjana (S1) seharusnya berjumlah 6.865 orang dan setengah dari guru yang sudah s1 merupakan guru yang sudah sertifikasi yaitu sebanyak 3.432 orang.

Apabila jumlah dalam satu sekolah belum terdapat guru yang s1 atau yang belum tersertifikasi maka pemerintah harus menganggarkan biaya untuk melanjutkan sekolah dan penyelanggaraan PLPG. Jika diasumsikan untuk menyelenggarakan PLPG untuk satu orang guru sebesar 5-6 juta, maka pemerintah harus mengkalikannya dengan jumlah guru yang belum sertifikasi. Jika di sekolah ditemukan masih ada guru yang belum S1 atau yang masih D3 maka pemerintahpun harus menganggarkan untuk biaya melanjutkan studi. Belum lagi jika ditemukan guru yang belum sesuai dengan jalur pendidikan, misalnya masih ada guru yang tidak linier latar belakang pendidikannya maka disarankan guru tersebut untuk melanjutkan pendidikan atau mengambil pendidikan yang sejalur yaitu PGSD.

Perencanaan tidak hanya dari bidang infrasturktur tetapi juga dari sumber daya dan dana yang dibutuhkan sehingga dari tahun sekarang pemerintah harus memiliki data tentang latar belakang gurunya, sehingga dapat menganggarkan uang biaya yang dibutuhkan dan ada target untuk mencapai itu sehingga masyarakat mendapatkan layanan pendidikan minimal sesuai dengan SPM yang telah dibuat.

Untuk mengetahui berapa biaya yang harus dikeluarkan oleh dinas pendidikan dalam meningkatkan kualitas guru, kita akan melihat pada kota cimahi dalam data BPS tahun 2011, yaitu: 
Tabel 7. Guru Menurut Jenjang Pendidikan

\begin{tabular}{|c|l|c|c|c|c|c|}
\hline No & \multicolumn{1}{|c|}{ Kecamatan } & SLTA & D1 & D2/D3 & S1/S2 & JUMLAH \\
\hline 1 & Cimahi Selatan & 94 & 9 & 131 & 671 & 905 \\
\hline 2 & Cimahi Tengah & 64 & 6 & 155 & 535 & 760 \\
\hline 3 & Cimahi Utara & 40 & 4 & 114 & 490 & 648 \\
\hline \multicolumn{6}{|c|}{ Jumlah Guru Keseluruhan } \\
\hline
\end{tabular}

Sumber: Hasil Olahan Penelitian

Melihat pada data diatas, ternyata masih banyak guru sekolah dasar yang tingkat pendidikannya D3 bahkan SLTA juga masih ada sehingga dinas harus dapat menganggarkan biaya untuk meningkatkan kualitas guru minimal dengan memberikan kesempatan guru untuk melanjutkan pendidikan sehingga semuanya S1 sesuai dengan kualifikasi. Bagian terpenting dari mutu pendidikan yang harus diberi prioritas pembiayaan adalah komponen guru sebagai sumber daya manusianya, ia merupakan pelaksana operasional pendidikan dalam belajar mengajar. Ia merupakan pencetak generasi masa depan yang berkualitas. Aktivitasnya dilakukan dalam proses belajar mengajar yang membuat kualitas pendidikan bermutu.

Peningkatan kemampuan guru dapat dilakukan melalui pelatihan dan penataran. Kegiatan tersebut memerlukan program yang relevan yang terencana dan periodik, supaya akses pencapaian mutu pendidikan baik secara internal maupun eksternal. Biayanya harus dianggarkan secara tepat dan baik dilihat dari kebutuhan pendidikannya maupun jenis pendidikan dan latihan yang diikutinya.

\section{Perencanaan}

pembiayaan

pendidikan tidak hanya berhubungan dengan pembiayaan yang berkaitan dengan kebutuhan peserta didik melainkan ada pembiayaan tehadap infrastruktur dan juga pengembangan profesional guru sendiri. Pembiayaan pendidikan merupakan instrumen penting dalam pencapaian tujuan, sebagus dan sehebat apapun program pendidikan itu tanpa konsep perencanaan pembiayaan yang matang maka program tersebut sulit untuk dapat direalisasikan. Kalaupun terrealisasi maka hanya menimbulkan keborosan biaya.

Dadang Dkk, (2012:5) menyatakan bahwa pembiayaan pendidikan adalah aktivitas pemenuhan tujuan permintaan kebutuhan manusia terdidik melalui belajar yang harus dibiayai. Pendidikan memproses manusia sehingga dapat menjadi manusia yang produktif. Modal yang ditanam pendidikan berperan seperti dalam dunia industri. Dalam dunia pendidikan, output pendidikan bukan berupa komoditi tetapi mencetak atau mengembangkan manusia terampil yang berkemampuan untuk membangun dan mengembangkan dirinya lebih baik. Keuntungan membangun pendidikan adalah manusia yang cerdas yang sanggup menggerakan sumber daya ekonomi sehingga ekonomi bergerak, masyarakat menjadi aktif dan segala kebutuhan hidup disediakan.

\section{E. KESIMPULAN}

Perencanaan pendidikan merupakan aktivitas pemenuhan tujuan kebutuhan manusia, dan kebutuhan tersebut harus dapat dibiayai agar dapat menunjang kehidupan manusia lebih baik dimasa yang akan datang. Kebutuhan di masa yang akan datang khususnya dalam dunia pendidikan berupaya mencetak dan mengembangkan manusia terdidik lebih berkualitas. Dalam dunia pendidikan khususnya sumber daya manusia, guru berperan aktif untuk mendidik generasi selanjutnya lebih berguna dan berkompeten. Dari data yang tersedia, 
kebutuhan guru ternyata masih terdapat kekurangan. Dimasa depan, pemerintah harus dapat mempersiapkan guru yang berkualitas dan anggaran yang memadai . Rencana penambahan guru per rombel di masa depan memerlukan program kegiatan dan anggaran, maka dari itu diperlukannya rencana biaya yang matang sehingga outputnya terlihat dalam kualitas pendidikan itu sendiri. Kegiatan dan pelatihan atau penataran untuk para guru pun dapat membuat kompetensi guru meningkat. Maka dari itu, diperlukannya rencana dan pendanaan yang efektif dan efisien agar program penambahan jumlah guru serta kegiatan program pelatihan dan penataran dapat dibiayai dan hasil maupun kualitasnya memuaskan. 


\section{Referensi}

Banghard, Frank W., \& Albert Trull Jr., (1973), Education Planning, New York: The Macmillan Co.

Blaug, Mark, (1970). Economics of Education. The Penguin Press.

Blocher, Chen, Cokins, Lin, (2007). Cost Management (Manajemen Biaya: Penekanan Strategis), Jakarta, Salemba Empat

Bowen, R. Howard, (1981). The Costs of Higher Education. Jossey-Bass Publishers.

Bray, Mark \& Thomas Murray R.,(1998). Financing of Education In Indonesia. Asian Development Bank. Comparative Education Research Centre. The University of Hongkong.

Biro Perencanaan, (2000). Perencanaan Pembangunan Pendidikan. Departemen Pendidikan Nasional. Jakarta.

Cohn, Elchanan, (1979). The Economics of Education, Revised Edition, Balinger Publishing Company, Cambridge, Massachusetts.

Coombs, H. Philip \& Hallak Jacques, (1972). Managing Educational Cost, Oxford University Press.

Dedi Supriyadi, (2003), Satuan Biaya Pendidikan, Dasar dan Menengah, Cetakan Pertama, Cv. Rosda Karya, Bandung.

DEPDIKNAS, (2001). Pedoman Penyusunan Standar Pelayanan Minimal Penyelenggaraan Persekolahan Bidang Pendidikan Dasar dan Menengah. Dirjen Pendidikan Dasar dan Menengah.
Proyek Peningkatan Sistem Evaluasi Nasional. Jakarta.

Dadang Suhardan, Ridawan Dan Enas. (2012). Ekonomi Dan Pembiayaan Pendidikan. Bandung: Alfabeta

Fattah, Nanang. (2009). Ekonomi dan Pembiayaan Pendidikan. Bandung: Remaja Rosdakarya.

Fattah, Nanang.(1999). Landasan Manajemen Pendidikan. Bandung: Remaja Rosdakarya

Peraturan Menteri Pendidikan Dan Kebudayaan Republik Indonesia Nomor 69 Tahun 2009 Tentang Biaya Operasi Nonpersonal

Peraturan Menteri Pendidikan Dan Kebudayaan Republik Indonesia Nomor 23 Tahun 2013 Tentang Perubahan Atas Peraturan Menteri Pendidikan Nasional Nomor 15 Tahun 2010 Tentang Standar Pelayanan Minimal Pendidikan Dasar Di Kabupaten/Kota

Pemerintah Nomor 19 Tahun 2007 Tentang Perubahan Atas Peraturan Pemerintah Republik Indonesia Nomor 75 Tahun 2005 Tentang Jenis Dan Tarif Atas Jenis Penerimaan Negara Bukan Pajak Yang Berlaku Pada Departemen Hukum Dan Hak Asasi Manusia

Sa'ud, Udin S. dan Makmun, Abin Syamsuddin. (2007). Perencanaan Pendidikan, Suatu Pendekatan Komprehensif. Bandung: Remaja Rosdakarya

Sagala, Syaiful. (2007). Manajemen Strategik Dalam Peningkatan Mutu Pendidikan. Bandung: Alfabeta

Bio Data Penulis. 
*) Dr. Dedy Achmad Kurniady, M.Pd. merupakan salah satu dosen di Jurusan Administrasi Pendidikan, FIP-UPI, Jl. DR. Setiabudhi No.229 Bandung 40154, Telepon: 022-2013163 ps.4307 dan 4318, HP. 08122106359, e-mail: dhieupi@yahoo.co.id

dedy_achmad@upi.edu., dan juga sebagai anggota divisi Riset, Training \& Community Development pada Laboratorium Administrasi dan Manajemen Pendidikan UPI. Disamping itu, buku yag pernah ditulisnya adalah (1) Manajemen Pembiayaan Pendidikan; (2) Manajemen Pendidikan Berbasis Multibudaya; dan masih ada 3 (tiga) buku yang saat ini sedang dalam proses pencetakan. Pada tingkat Jurusan (S1) dipercaya untuk mengampu mata kuliah:

(1) Pengelolaan Pendidikan;

Manajemen Keuangan Pendidikan; (3)

Manajemen Pendidikan Berbasis

Multibudaya; (4) Manajemen Hubungan

Sekolah dengan Masyarakat; dan (5) Sistem Informasi Pendidikan. Sedangkan pada tingkat Pasca Sarjana di Program Studi Administrasi Pendidikan dipercaya untuk mengampu mata kuliah: (1) Pembiayaan Pendidikan; (2) Landasan Manajemen Pendidikan; (3) Management Strategic; dan (4) Metodologi Penelitian Administrasi Pendidikan. Adapun pengalaman pekerjaan yang pernah dilakukan meliputi : Anggota Tim Parancang Analisis Biaya Satuan Madrasah pada Balitbang Depag, (2006); Anggota Tim Pelatihan Kewirausahaan bagi PNSD Pra Purnabakti Pemda Provinsi Jawa Barat (2007); Anggota Tim Peneliti Strategi Pembiayaan Pendidikan Kota Bandung (2007); Anggota Tim Pelatihan Kewirausahaan bagi PNS Pra Purnabakti Pemda Provinsi Jawa Barat (2008); Anggota Tim Analisis Budget Mapping Pembangunan Pendidikan Kabupaten Bandung (2008). TIM Pengembang ISO 2008:9001, di tingkat Fakultas (2012), Menjadi Fasilitator Bimtek di lingkungan P2TK Dikdas dan Penyusunan pedoman-pedoman yang berkaitan dengan pengembangan Tenaga Kependidikan (2014); Ketua Peneliti tentang Efektivitas dan Efisiensi Pembiayaan Pendidikan Pada Sekolah Dasar Di Kabupaten Bandung (2012); Menjadi Anggota pada penelitian Program Kemitraan untuk Pengembangan Kapasitas dan Analisis Pendidikan Studi Dasar Kompetensi Kepala Sekolah/Madrasah dan Pengawas Sekolah/Madrasah di Kota Bandung (2013).

**) Gilang Gumilang dan Herlina, merupakan mahasiswa lulusan S-1 Administrasi Pendidikan, dan saat ini sedang melanjutkan perkuliahan ke jenjang S-2 di Pasca Sarjana UPI pada Program Studi Administrasi Pendidikan. 